\title{
How Corporate Ethical Values and Ethical Leadership Influence on Religious Commitment? A Study on Sharia Banks Indonesia
}

\section{Titiek Ambarwati, Fika Fitriasari, R. Iqbal Robbie, and Ardik Praharjo}

Muhammadiyah University of Malang Department of Management, Business and Economic's Faculty

\section{Abstract}

The main goals of this paper is to explore (1) the influence of firm's ethical value to ethical leadership and organizational commitment, (2) the influence of ethical leadership to organizational commitment, and (3) the impact of religiosity as a moderating variable to the relationship of ethical leadership toward organizational commitment on Syariah Banks in Pasuruan and Probolinggo City, Indonesia. This study is an explanatory research that held by quantitative method. To collect the data a survey

Corresponding Author:

R. Iqbal Robbie

iqbal_robbie@umm.ac.id

Received: 10 February 2019

Accepted: 14 March 2019

Published: 28 March 2019

Publishing services provided by Knowledge E

(c) Titiek Ambarwati et al. This article is distributed under the terms of the Creative Commons Attribution License, which permits unrestricted use and redistribution provided that the original author and source are credited.

Selection and Peer-review under the responsibility of the ICIEBP Conference Committee. using questionnaire as an instrument of the research was filled out by 109 respondents as the research's sample. The population of this research is the employees of both the state-owned enterprises and private Syariah Banks in Pasuruan and Probolinggo city. The population involve all the permanent employees besides the top level manager of those Syariah Banks. Data obtained from the questionnaire was analysed with Partial Least Square method. This study found that firm's ethical value has significant influence toward ethical leadership and ethical leadership has significant influence toward organizational commitment, but firm's ethical value has found no significant relationship to organizational commitment. This study also found that religiosity be able to mediate the indirect relationship between ethical leadership and employee's organizational commitment. This paper give contribution to the firms that religiosity has a moderating effect that can improve the relationship between ethical leadership toward organizational commitment.

Keywords: Religiosity, Firm's Ethical Value, Ethical Leadership, Commitment

\section{Research Background}

Firm's ethical value will form employee's commitment and performance, because firm's ethical value is a guideline for the procedure that planned and also code in carrying out actions that distinguish between what is right and what is wrong. The quality of the firm's ethical values can be achieved when the leaders and employees are strictly following the rules and regulation (Hunt, 1989). Thomsen (2004) defines the firm's ethical value 
as a form of decision making that attached to alternative goals. A broader firm's ethical value can be seen as the reflection of organization's philosophy, organization's ethics, and the responsibility principle to different stakeholders. Firms usually state their ethical values on official websites or in written ethical code. The ethical code will shows the company's awareness to ethical issues and also shows how to apply the ethical values in the organizational activities (Kaptein, 2004).

There are lots of studies about this topic, but there is an inconsistency among those studies. According to Zain et al., (2009) work, organizational culture has a positive impact on commitment, but in Erben and Guneser (2008) has found that organizational culture have positive influence to affective commitment continuance commitment, but have negative influences to normative commitment. Many studies analyze how the contents of the code of ethics in the company, such as the one stated by Riivari (2012), which examines the influence of corporate ethical values on organizational innovation, the result is a positive influence on the company's ethical values of innovation. These results indicate the organizational climate formed by the company provides space for employees to bring up ideas and creativity in advancing their organization.

In conjunction with organizational commitment there are also inconsistencies, according to Zain et al., (2009) Organizational culture has a positive influence on commitment, but according to Erben and Guneser (2008) Organizational culture influences affective and continuous commitment, but negatively affects normative commitment. This shows that the organizational culture has not been able to provide an impact that strengthens the physical and spiritual bonds to employees. Similarly, ethical leadership is positively related to middle manager job satisfaction and organizational commitment (Kim \& Brymer, 2011). Conformity between leader moral development and employee moral development can positively influence job satisfaction and organizational commitment, and negatively related to intention to leave (Schminke, Ambrose, \& Neubaum, 2005). Many are researching organizational culture, but there are still few who examine the company's ethical values.

This study was carried out to the employees of Syariah Bank that located in Pasuruan and Probolinggo City. Those cities belong to Pandalungan area, which the peoples in this area really attached in implementing the islamic values in their daily activities. This study was held in the employees of Syariah Bank, so the writers assume that religiosity is a factor which can fill the existing research's gap. The writer's assumption is based on the definition of religiosity. Religiosity is an individual belief or faith to God which can be expressed by commitment, so religiosity can be expected as a moderation variable 
on the relationship between the firm's ethical values and ethical leadership towards employee commitment and performance.

\section{Literature Review and Research Framework}

\subsection{Firm's ethical values and ethical leadership}

The firm's ethical value scale from Hunt, et al. (1989) is often used as a tool to measure actions that related to employees' ethical perceptions. Firm's ethical values can be explained as part of an organizational culture that represents the interactions between various multidimensional, formal and informal behavioral control systems (Trevino et al., 1998). Informal systems consist of values, attitudes, norms, perceptions and beliefs in the organization (Key, 1999; McDonald and Nijhof, 1999). The firm's ethical values also can be expressed in a formal structure such as compensation methods, institutional procedures, and applicable regulations.

Brown et al. (2005) has explained that "Moral person" are those who behave normatively, so their behavior will be such a honest, trustworthy, credible, fair in making decisions, and have ethical principles. Whereas the "Moral Manager" in the dimension of ethical leadership means, the leader is overt about ethical issues and empowers employees to act fair. This aspect also shows the proactive efforts of a leader in influencing employees' to implementing ethical behavior in their actions. Moral managers can demonstrate the implementation of the ethical behaviour by strengthening the work mechanisms such as reward, discipline, and responsible for every actions and decisions they take. In some previous studies about the firm's ethical value there is an discrepancy result. Such as Rehman's work (2012) that found a significant influence between the firm's ethical value towards ethical leadership, but Schimmuller (2012) explains that certain organizational cultures will influence leadership positively, negatively and have no effect at all. In the previous study in above, the relationship between the ethical values of the company as part of organizational culture in relation to leadership.

There is another study about ethical values of a firm and organizational commitment, the study was conducted by Zain, et al. (2009) that explain organizational culture has a positive influence on employee commitment, this is contrary to research conducted by Erben and Guneser (2008) which found that organizational culture only has a significant influence on affective and continuous commitment, but does not affect normative commitment. But Sabir's (2012) work shows that culture not be able to 
influence performance unless mediated by leadership. Sabir's works was conducted on banking, manufacturing, hotels and private companies in Pakistan.

\subsection{Islamic organizational commitment}

Mathis and Jackson (2000) defines the organizational commitment as the degree to which employees believe in and accept organizational goals and desire to remain with the organization. Robbins (1989) defines the organizational commitment as an attitude that reflects like or dislike feeling of employees towards the organization. Steers and Porter (1983) have explained the commitment that emerges is not just a passive loyalist, but also involves an active relationship with the organizations to give the best the effort for the organization success.

Theoretically, organizational commitment has three components (Meyer and Allen, 1991): (1) Affective commitment, is an employee's emotional attachment to the organization. (2) Continuous commitment, is the perceived economic value that employees get form organization compared to whe the employee leave it, for example: employees remain in an organization because they want the salary or other benefits. (3) Normative commitment, is the obligation to remain with the organization because of moral or ethical reasons. Employees remain with organization because they realize that commitment to the organization is something that they should do.

Iltizam is a word that can generally define as a commitment to religion or something else. As for now the term of iltizam is expressed by istiqomah to the syariah and heading toward religion. Iltizam is Al Istiqomah. Allah said: "Verily those who say:"Our Lord is Allah", then they remain istiqamah so there is no concern for them and they do not (also) grieve" (Surat al-Ahqaaf: 13). Istiqomah means the straight path that does not turn also does not deviate. Commitment in islamic syariah is called istiqomah, which is a consistent behavior to keep going on a straight path despite of many obstacles (Tsamara, 2010). Consistent behavior will evoke the confidence and integrity, so employee wiil be respond the challenges as a pleasure things. In this study, researchers will use several items to measure employee's commitments from the Holy Qur'an, Hadith, and the previous study conducted by Munawaroh (2012), that is:

1. Istiqomah hati: is when people always mantain the purity of their faith by mantain the purity of their heart from shirk, stay away from the bad deeds like riya' and keep doing the good deeds especially sincerity. In the concept of organizational commitment proposed by Allen and Meyer, Istiqomah hati is almost the same as 
Normative Commitment that is the desire of a person or individual to survive in a company because of ethics.

2. Istiqomah lisan: is when people always maintain the oral or spoken words from nonsense, so they always say about the truth, honest things, and harmoniously withh the heart that holding toward the principle of truth and does not pretend. Oral Istiqomah is only owned by people who believe and dare to declare and defend the truth, and only fear Allah.

3. Istiqomah perbuatan: is when people diligently working or doing deeds and all efforts to achieve glory that blessed by Allah, in other words, istiqomah perbuatan is dedication to do the taks or struggle to uphold the truth without feeling disappointed, lacking enthusiasm, or despair.

In the concept of organizational commitment that proposed by Allen and Meyer, this consistent with the Continuous Commitment. Continuous Commitment is the desire of employees to stay in the company because they want to get rewards or salary after doing a job.

\subsection{Religiosity}

Mc Donnel and Burnett (1990) define Religiosity as trust in God which is indicated by a commitment to carry out all of His commands. Allport and Ross (1967) has explained that there are two types of religiosity, that is: extrinsic religious orientation and intrinsic religious orientation. Extrinsic religious orientation is a form of religiousityof an individual that expressed by doing cooperation or affiliation with others. Intrinsic religious orientation is a form of religiosity that an individual looking for perfection of he's/she's own practice. In extrinsic orientation shows affiliation with others, so that later will be known how the influence of leadership on employee commitment (Mansoor, 2014).

\section{Research Conceptual Framework}

\section{Research Hypothesis}

H1: Firm's ethical values has a significant infuence to ethical leadership

$H 2$ : Stronger ethical leadership will influence the employee's organizational commitment 


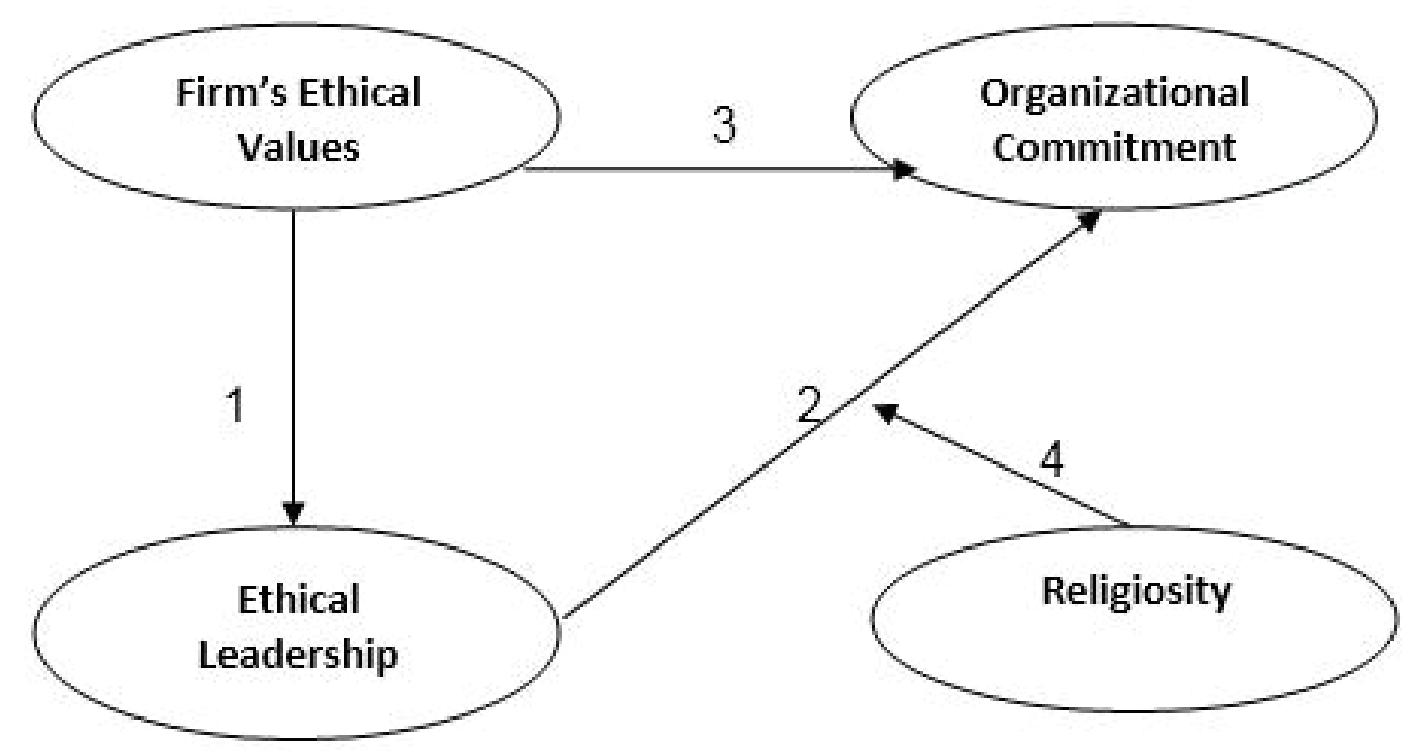

Figure 1: Research Conceptual Framework.

H3: Stronger Firm's ethical value will influence the employee's organizational commitment

H4: Religiosity has a moderating effect to the relationship between ethical leadership to employee's performance in Bank Syariah Pasuruan and Probolinggo.

\section{Research Method}

\subsection{Population and sample}

The Population in this study are the employees at Syariah Banks in Probolinggo and Pasuruan. Total samples in this study are 109 respondents, which are employees of Syariah Banks include all permanent employees besides the top level managers. The purpose of not involving top level managers as the research sample is this research want to assess the ethical leadership of employees towards the organization/ firm.

\subsection{Data collection and analysis method}

The data of this study were collected from primary source by giving questionnaires to the respondents or research's sample which has been specified. Distribution of questionnaires was held during January until March 2018. Alll of the items in the questionnaire were arranged based on the indicators of each variables. This study also use secondary data that obtained from in depth interviews to explain questions 
and get answers as desired and supported by various previous studies. Data obtained from the questionnaire was analized with Partial Least Square method. The hypothesis testing is done by looking at the probability value and the t-statistics. The probability values or the $p$-value with alpha $5 \%$ should be less than 0.05 . The $t$-table value for alpha $5 \%$ is 1.96 . So the hypothesis is accepted when t-statistics $>$ t-table.

\section{Results and Discussion}

Out of 109 employees in Syariah Banks in Pasuruan Cand Probolinggo City, most of employees who participated in this study $59.6 \%$ was male, and $40.4 \%$ was female employees. Out of 109 employees in Syariah Banks in Pasuruan and Probolinggo City who participated in this study $49.5 \%$ of employees are $26-30$ years old. Then $25.7 \%$ of employees are 20-25 years old. Furthermore, $22.9 \%$ of employees $31-40$ years old. $1.8 \%$ of employees are $31-50$ years, and none of the employees are more than 50 years old. Based on the results in the table above, we also konw that out of 109 employees in Syariah Banks in Pasuruan and Probolinggo City who participated in this study, 48.6\% of employees have worked for 1-3 years. Then $34.9 \%$ of employees have worked for 4-6 years, and $16.5 \%$ of employees have worked for more than 6 years.

\subsection{Partial least square (PLS) analysis validity test}

\section{TABLE 1: Validity Test.}

\begin{tabular}{l} 
Variable \\
Firm's Ethical Values \\
Ethical Leadership \\
Organizational Commitment \\
\hline Religiosity
\end{tabular}

Dimention
System Formal
System Informal
Moral Person
Moral Manager
Istiqomah Hati
Istiqomah Lisan
Istiqomah Perbuatan
Intrinsic Religiosity Orientations
Extrinsic Religiosity Orientations

\begin{tabular}{|c|}
\hline $\begin{array}{c}\text { Loading } \\
\text { Factor }\end{array}$ \\
\hline 0.907 \\
\hline 0.925 \\
\hline 0.574 \\
\hline 0.918 \\
\hline 0.683 \\
\hline 0.611 \\
\hline 0.867 \\
\hline 0.853 \\
\hline 0.797 \\
\hline
\end{tabular}

Based on the analysis of the 2 nd order measurement model, it can be seen from the Table 1. all of the dimensions that used to measures the variables, that is firm's ethical value, ethical leadership, organizational commitment, and religiosity produce loading 
factor greater than 0.5. Thus, this dimensions can be stated as valid or able to measure the firm's ethical values, ethical leadership, organizational commitment, and religiosity

\subsection{Reliability test}

To test the constructs reliability it can be seen by the value of cronbach alpha and composite reliability. The criterias of reliability test are if the composite reliability is greater than 0.7 (Hair, et al., 2014) and cronbach alpha is greater than 0.6, so the construct is can be stated as reliable (Hair, et al., 2014).

TABLE 2: Reliability Test.

\begin{tabular}{|l|c|c|}
\hline Variable & $\begin{array}{c}\text { Composite } \\
\text { Reliability }\end{array}$ & Cronbachs Alpha \\
\hline Firm's Ethical Values & 0.912 & 0.836 \\
\hline Ethical Leadership & 0.728 & 0.845 \\
\hline Organizational Commitment & 0.768 & 0.808 \\
\hline Religiosity & 0.810 & 0.835 \\
\hline Goodness of Fit Model & & \\
\hline
\end{tabular}

TABLE 3: Goodness fit of model.

$\begin{array}{lc}\text { Variable } & \mathbf{R}^{2} \\ \text { Ethical Leadership } & 0.628 \\ \text { Organizational Commitment } & 0.337 \\ \mathrm{Q}^{2}=1-\left(1-\mathrm{R} 1^{2}\right)\left(1-\mathrm{R} 2^{2}\right)\left(1-\mathrm{R} 3^{2}\right) \rightarrow & \\ \mathrm{Q}^{2}=1-(1-0.628)(1-0.337)(1-0.549)=0.889\end{array}$

The R-square of the ethical leadership variable is 0.628 or $62.8 \%$. This is indicate that the diversity of ethical leadership variables is explained by the firms's ethical value variable $62.8 \%$, or in other words the contribution of the firm's ethical value variable to ethical leadership variable is $62.8 \%$, while the remaining $37.2 \%$ is the contribution of other variables that not included in the this study.

The R-square of organizational commitment variable is 0.337 or $33.7 \%$. This number indicate that the diversity of organizational commitment variable is explained by the variables of ethical leadership and religiosity by33.7\%, or in other words the contribution of ethical leadership and religiosity variables to organizational commitment variables by $33.7 \%$, while the remaining $66.3 \%$ is the contribution of other variables that not discussed in this study. Q-Square predictive relevance $(Q 2)$ is 0.889 or $88.9 \%$. This number show that the diversity of performance variables can be explained by the overall 
model of $88.9 \%$, or in other words the contribution of ethical leadership, organizational commitment, and religiosity to the overall performance variable is $88.9 \%$, while the remaining $11.1 \%$ is the contribution of other variables that not discussed in this study.

\subsection{Hypothesis testing result}

TABLE 4: Hypothesis Testing Results.

$\begin{aligned} & \text { The relationship } \\ & \text { of variables }\end{aligned}$
Firm's Ethical
Values $\rightarrow$ Ethical
Leadership
Firm's Ethical
Values $\rightarrow$
Organizational
Commitment
Ethical Leadership
$\rightarrow$ Organizational
Commitment
Ethical Leadership
${ }^{*}$ Religiosity $\rightarrow$
Organizational
Commitment

\begin{tabular}{c}
$\begin{array}{c}\text { Original Sample } \\
(0)\end{array}$ \\
0.79 \\
\hline 0.09 \\
\hline 0.58 \\
\hline
\end{tabular}
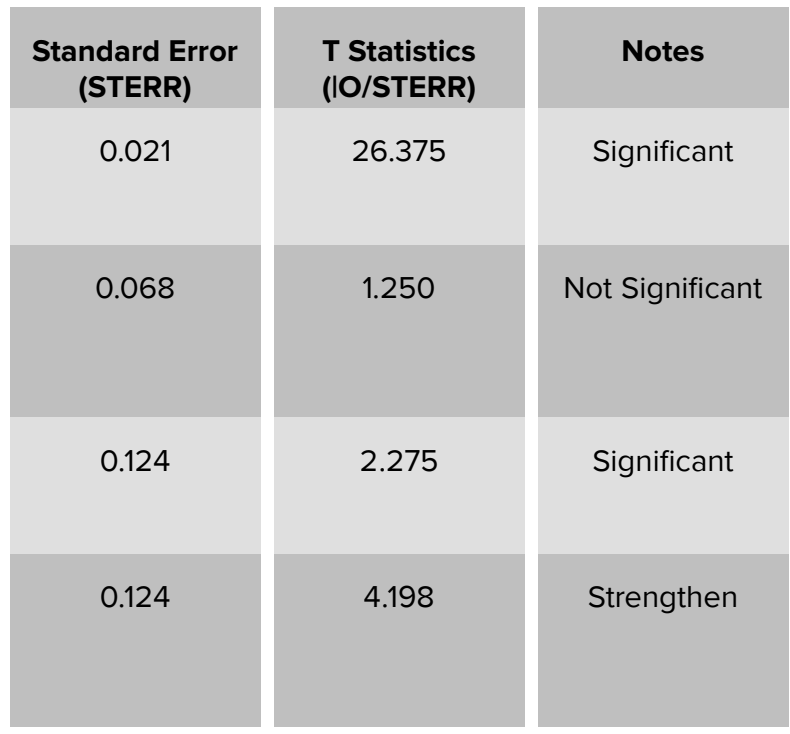

\subsection{Implication}

1. This study's finding confirms that firm's ethical value must be strengthened by a good system. The formal system will be used as rules or regulations that will tie up all of the organization's members.The Informal system will support the formal system in strengthen the relationship between company members.

2. The findings of this study confirm that religiosity has a positive impact on the individual, compliance and obedience of employees play a role in the company's environment. The positive impact between ethical leadership and employee's commitment is increase with employee religiosity factors, Religiosity has an impact to strengthen the relationship that occurs in employee's commitment.

\subsection{Practical contribution}

1. This study provides direction to managements that they are need the firm's ethical value as a working culture that can be used to increase the support for employee 
leadership and performance. Strengthening the existing system, running the system seriously is an obligation for all members of the company. Especially in the Syariah Bank environment, the Syar'i stamp will automatically be attached, this will be seen by the public whether the behavior of all company members reflects ethical attitudes or not. Thus, the more the system is strengthened, the public trust is expected to increase.

2. All members activities and actions of the company, especially the leader activities in carrying out ethics both business ethics and ethical behavior, are the main capital to improve organizational commitment. The improvement of commitment is expected to have a positive impact on the company to compete with other conventional banks, create partnerships with the community, businesses, or fair competition with other companies.

\subsection{Research limitation}

1. This study see performance from the employee perspective not from the company perspective. As such, these results are limited only from the perspective of employees or individuals.

2. This study only conducted to all employees besides the top level managers of Syariah Banks in Pasuruan and Probolinggo City. Thus, the results of this study's scope is local and cannot be generalized to all situations.

3. This study only aplicable in banking companies, not in the other types of companies, such as manufacturing and trading etc. So the findings of this study cannot be generalized in all types of companies.

\subsection{Conclusion and suggestion conclusion}

1. The firm's culture is very important to all organization members, the ethical value of the firm will be personally tied up every organization member. The findings of this study indicate that the firm's ethical value is an important guideline for management. A well-managed system, with improvements will strengthen the influence of ethical value on the daily management activities.

2. The informal system in the dimensions of the firm's ethical values must be optimized so that it can be an agent of change that will provide examples of behavior to understand and morally tie up the employees. 
3. The stronger ethical leadership factor as well as the employee's commitment and performance. This finding also shows the strength of the leadership factor determined the improvement of the firm's operations performance.

4. The employee's commitment has influence on performance, especially the higher religious commitment that in turn will be an individual identity which is will build the characteristic of the company.

5. Religiosity is a personal factor, this is indicated by the intrinsic factor that religiosity is obedience to the Almighty God, but religiosity also can occur within the workplace, religiosity maintain the adherence to ethical leadership and religiosity towards individual performance

\subsection{Suggestion}

1. The Firm's Ethical Values are very difficult to be thought to, but can be learned through theculture continuously, the findings of this study indicate that the rules of organizational culture begin with being ethical and complying the legal provisions. Understand about the importance of ethical and law-abiding factors directly or indirectly will help explain that management has carried out cultural practices maximally. Therefore, management needs to explore ethical and legal factors so it can facilitate the understanding about how to shape and strengthen the firm's ethical values and reducing the gap between management and its stakeholders.

2. Management should pay attention to the religiosity of company members. Every stakeholder has a different depth of religiosity so the approach to each stakeholder is different.

\subsection{Suggestion for the future study}

1. It is necessary to do in the future research, to change the perpective of the employee performance to the perspective of other stakeholders, for example from company performance to find common ground and differences in views between employees and companies.

2. Further research is needed to explore the company's ethical value from the perspective of non-banking private companies magement, for example the manufacturing industry and other companies with different locations. 


\section{References}

[1] Al Qur'an. 2014. Al Qur'an dan terjemahnya. Kementerian Agama Republik Indonesia, Penerbit Sahifa. Tangerang Banten

[2] Allen, N. and Meyer, J.1990. The measurement and antecedents of affective, normative and continuance commitment to the organization. Journal of Occupational Psychology, Vol. 63,pp. 1-18.

[3] Allport GW and Ross JM.1967. Personal religious orientation and prejudice. Journal of personality and social psychology. 432-443

[4] Brown, M. E., and Treviño, L. K. 2006b. Socialized charismatic leadership, values congruence, and deviance in work groups. Journal of Applied Psychology, 91,954962.

[5] Brown, M. E., Treviño, L. K., and Harrison, D. A. 2005. Ethical leadership: A social learning perspective for construct development and testing. Organizational Behavior and Human Decision Processes, 97, 117-134.

[6] Dheeraj Sharma. 2018. When Fairness is Not Enough: Impact of Corporate Ethical Values on Organizational Citizenship Behaviors and Worker Alienation. Journal of business ethics, Vol. 148.

[7] Erben and Guneser. 2008. The relationship between paternalistic leadership and organizational commitment: investigating the role of climate regarding ethics. Journal of Business Ethics.

[8] Hair, J. F., Hult, G. T. M., Ringle, C. M., and Sarstedt, M. 2014. A Primer on Partial Least Squares Structural Equation Modeling (PLS-SEM). Thousand Oaks, CA: Sage.

[9] Hunt, S.D., Wood, VR. Chonko LB.1989. Corporate ethical values and organizational commitment in marketing. Journal of marketing. 53 (3).

[10] Kaptein. 2004. Business Codes of Multinational Firms: What do They Say?. Journal of Business Ethics 50, pp. 13-31.

[11] Mathis, L Robert and Jackson H. John. 2006. Human Resource Management,Ninth Edition, USA: South Western College Publishing

[12] M. dan Porter, L.W. 1979. The measurement of organizational commitment. Journal of Vocational Behaviour, Vol. 14, pp. 224-47.

[13] Munawaroh, SJ. 2012. Pengaruh spiritualitas terhadap perilaku istiqomah dan etos kerja pada guru yang beragama islam. Sekolah Tinggi Agama Islam Negeri Salatiga

[14] Nadia, Iqbal. 2013. corporate ethical values, group creativity, job commitment and performance: the effect of work response onwork context. 
[15] Rehman Toor. And Ofori. 2009. Ethical leadership: examining the relationship model, employee outcomes and organizational culture". Journal of business ethics

[16] Robbins, S.P. 2005. Organizational behavior. 11ed editions. Prentice Hall, Englewood, NJ Thomsen "Corporate Values and Corporate Governance," Corporate Governance, Vol. 4 No. 4, 2004, pp. 29-46. 